University of California, Hastings College of the Law UC Hastings Scholarship Repository

Faculty Scholarship

2018

\title{
Mobilizing International Law in the Palestinian Struggle for Justice
}

George Bisharat

UC Hastings College of the Law, bisharat@uchastings.edu

JeffHandmaker

Ghada Karmi

Alaa Tartir

Follow this and additional works at: https://repository.uchastings.edu/faculty_scholarship

\section{Recommended Citation}

George Bisharat, Jeff Handmaker, Ghada Karmi, and Alaa Tartir, Mobilizing International Law in the Palestinian Struggle for Justice, 18 Global Jurist (2018).

Available at: https://repository.uchastings.edu/faculty_scholarship/1699

This Article is brought to you for free and open access by UC Hastings Scholarship Repository. It has been accepted for inclusion in Faculty Scholarship by an authorized administrator of UC Hastings Scholarship Repository. For more information, please contact wangangela@uchastings.edu. 


\title{
Mobilizing International Law in the Palestinian Struggle for Justice
}

\author{
${ }^{1}$ University of California Hastings College of the Law, San Francisco, CA 94102-4978, USA \\ ${ }^{2}$ Erasmus Universiteit Rotterdam Faculteit der Sociale Wetenschappen, Rotterdam 3000 DR, Netherlands, E-mail: \\ Handmaker@iss.nl \\ 3 University of Exeter, Institute of Arab and Islamic Studies, Exeter, United Kingdom of Creat Britain and Northern Ireland \\ ${ }^{4}$ The Graduate Institute of International and Development Studies (IHEID), Centre on Conflict, Development and \\ Peacebuilding (CCDP), Chemin Eugène-Rigot 2A, Case postale 1672, 1211 Genève 1 Geneva, Switzerland, E-mail: \\ alaa.tartir@graduateinstitute.ch. http://orcid.org/0000-0002-3383-0356.
}

\begin{abstract}
:
Those involved in mobilizing international law to achieve justice for the Palestinians have invoked numerous legal and governance institutions, at both international and national levels. For various reasons, international law has understandably been regarded with a high level of skepticism by many Palestinians, particularly from legitimacy and effectiveness standpoints. However, law has also ignited the Palestinian civic imagination and has led to bold and creative initiatives, including efforts to hold both states and (corporate) non-state actors accountable through legal and other means, and even to construct alternative models for nation building. This introduction to a Special Issue of the Global Jurist on 'International Law and the State of Israel' emerges from an international conference that took place at Cork City Hall and at the campus of University College Cork in Ireland in March 2017. Our message for producing this Special Issue and indeed for our colleagues who organized the conference in the first place was simple: while we cannot afford to neglect law in envisioning alternative futures in Israel/Palestine (including statehood), justice always remains a guide.
\end{abstract}

Keywords: international law, israel, justice, legitimacy, palestine

DOI: $10.1515 / g j-2018-0034$

\section{The two faces of law}

Law always has two main faces: the face of justice and the face of power. The impasse between the State of Israel and the Palestinians remains as persistent as ever, and contrary to popular perceptions, goes back a hundred years to the period of the British Mandate. ${ }^{1}$ On the one hand Israel has demonstrated a highly exceptionalist, disregard for international law, while on the other hand, a wide array of actors have persistently mobilized the law as a form of counter power. While Israel single-mindedly strives to instrumentalize law in order to secure its claimed legitimacy as a 'Jewish' state, others engage in legal mobilization as part of a much broader struggle for justice, whether in underpinning a global campaign for boycott, divestment and sanctions, to justify the intervention by activists who are trying to bring humanitarian aid to Palestinians in Gaza facing an illegal blockade and an Israeli-Egyptian siege or in other ways. ${ }^{2}$

Those involved in mobilizing international law to achieve justice for the Palestinians have invoked numerous legal and governance institutions, at both international and national levels. Due to Israel's disregard for international law and privileged treatment by powerful countries unconcerned by its repeated violations of human rights, international law has understandably been regarded with a high level of scepticism by many Palestinians. However, law has also ignited the Palestinian civic imagination and has led to bold and creative initiatives, including efforts to hold both states and (corporate) non-state actors accountable through legal and other means, and even to construct alternative models for nation building.

This Special Issue of the Global Jurist on 'International Law and the State of Israel' emerges from an international conference that commenced at Cork City Hall and at the campus of University College Cork in Ireland in March 2017. While it was impossible to include most, let alone all contributions, our message for producing this Special Issue and indeed for those who organized the conference in the first place was simple: while we cannot afford to neglect law in envisioning alternative futures in Israel/Palestine (including statehood), justice always remains a guide. 
This may strike our readers as a platitude. No one opposes the value of justice as a general concept, and international law provides for ample possibilities to recognize different constructions of statehood. However, justice is all too often obscured, particularly in discussions around statehood and self-determination of the Palestinian people.

The quest for a Palestinian state began as a means to realize Palestinian rights. However, this has seemingly morphed into a quest for a state as an end in itself. There has been limited, critical regard to the nature of that Palestinian state, let alone its capacity to actually deliver justice for Palestinians. ${ }^{3}$ There has been even less scholarly attention on these issues with regard to Israel's claim to be a liberal democratic state. ${ }^{4}$ This condition of legal uncertainty and political confusion has resulted in the emergence of two Palestinian regimes (FatahHamas), in separate geographical enclaves, each exhibiting authoritarian tendencies that seem more likely to serve as coffins for the burial of Palestinian rights than vessels for their fulfilment.

In light of this rather dismal set of realities, we feel that re-centring justice and critically revisiting the concept of statehood is both a moral imperative and a pragmatic political necessity. This allows us to contemplate various facets of justice that in turn allow us both to critically assess the capacity of international law to deliver justice for Palestinians, and to contemplate how justice would be enhanced by the principle of state legitimacy. In particular, this Special Issue advances critical and fresh arguments as they relate to Judaic challenges to the legitimacy of Israel, legitimate citizenry, and the notion of a democratic state in Palestine/Israel.

\section{Re-centering justice - the Palestinian movement revisited}

In order to critique a Palestinian concept of justice, it is necessary to look back to the early days of the movement. As documented by Walid Khalidi, Nur Masalha, Ilan Pappé, Avi Shlaim and others, Palestinian opposition to Zionist colonization began as a struggle for justice, first and foremost against the forced displacement of Palestinians in favour of Zionist settlers and the denial of the right to return that Palestinians call the Nakba. ${ }^{5}$ Indeed, the Nakba, defined as the forced displacement of Palestinians for Jewish settlement, continues, as several have observed at the conference in Cork, and in this Special Issue, albeit adopting shifting forms.

The struggle for justice, therefore, has been at the core of the Palestinian struggle to halt the Nakba and to reverse its effects, to the maximum extent possible. Understandably, this struggle has focused on righting the legal wrongs committed against the Palestinian people.

But Palestinians have also embraced broader goals. This was particularly evident in the Palestine Liberation Organization (PLO)'s early adoption of the goal of a democratic secular state in Palestine, which was upheld as part of a vision of a progressive society, in which all peoples could live in peace, security, and prosperity under a regime of equal rights and mutual respect. That was in any event the vision of many PLO supporters early days of the Palestinian movement, which ultimately captured the imaginations of millions if people throughout the world, particularly following Israel's military incursions and massive expansion of territory in 1967. 6 The role of the popular committees during the first intifada, based on popular education and revolutionary justice, was - like many other revolutionary movements - somewhat mixed, but certainly embraced the collective Palestinian vision of justice, equal rights and self-determination. ${ }^{7}$

\section{Justice as the prescription}

So, in light of this early, secular vision of statehood, why is re-centring justice as our end goal a prescription for the ills we currently face, especially as we witness the Zionist colonizing juggernaut rolling forward, with nothing on the horizon even to slow its advance? Does it make sense to double down on justice and even to expand our ambitions when we have failed to achieve justice in even a minimal form? Is it right to affirm tolerance and inclusion against the headwind of rising right wing ethnic nationalism, in which Israel is ahead of the global curve by a decade or two?

These are serious questions. Part of the current weakness of the Palestinian movement for statehood is that there have been too many compromises on matters of principle. The result has been internal division and a deflation of the movement, and less international solidarity. Soft power, to recall Richard Falk's opening statement at the Cork Conference and developed in his 2017 book Palestine's Horizon Toward a Just Peace, can only be enhanced by adopting a broad vision of justice. 


\section{Seven facets of justice}

But invoking "justice" in the abstract is not enough. Seven facets of justice, to our mind, merit consideration, although this cannot be regarded as an exhaustive list.

The first is original justice; by this we mean that while a broader conception of justice is called for today than in the past, the original core rights of the Palestinian people remain the bedrock of a just resolution. It is the Palestinians who were the first, and remain the primary victims of Zionism, and whose rights remain in most urgent need of restoration. We are building on, not discarding, earlier conceptions of justice.

Here we wish to underscore that we mean the entire Palestinian people, including the majority who are refugees living in internal or external exile and those who live as second-class citizens within Israel, but lack Israeli nationality, let alone a privileged Jewish nationality. Ensuring the full recognition and participation of Palestinian refugees is crucial for any peace process. ${ }^{8}$

This leads us to a second facet of justice. Early on, Palestinians recognized that justice for themselves could not be injustice for others, but there was a need to more fully elaborate a conception of what might be called protective justice. We would benefit by a compassionate declaration along the lines of South Africa's Freedom Charter outlining how our conception of justice also includes Israeli Jews, who will continue to inhabit whatever state entity emerges, which for present purposes we refer to as Israel/Palestine. The challenge is to maximize rights for all in what a growing scholarship argues can only be realistically contained in one-state. ${ }^{9}$

As Jeff Halper highlights in his contribution, whether the land is shared in one state, two, or two dozen, we need a vision of a future society that respects and strives for justice for all. The more concrete we can be the better; for example, about the status and rights of secondary occupants - Israeli Jews - who currently inhabit former Palestinian homes, and to outline a process that treats them justly and with respect and dignity. ${ }^{10}$ While international law proscribes many current Israeli policies and bars certain outcomes, for example, by criminalizing apartheid, it otherwise only loosely structures how such a resolution could be achieved. Balancing legal and practical political considerations, in particular the necessity of winning Israeli Jewish "buy in" to power sharing with Palestinians, Halper reviews various structural options and concludes that a single democratic state that recognizes both individual rights and collective rights (without fully institutionalizing bi-nationalism) holds the greatest future promise.

In this regard we also must think beyond the binary of Israeli Jews/Palestinian Arabs, which flattens and masks diversity on both sides. There are many considerations here, but the salient one to us concerns Mizrahi Jews, who we would count as Zionism's second major category of victims. From the destabilization of their communities in the Arab world that Zionism caused, to the discrimination and racism those who settled in Israel have faced from Jews of Ashkenazi descent, Mizrahi Jews have suffered largely in obscurity. Mending their wounds will be a complex challenge, and in part implicates regional considerations.

South Africa provides us a model for thinking about a third facet of justice. South Africans conducted a partially successful experiment in what is sometimes called transitional justice. While, for Palestinians, transition still lies ahead, we can start conceptualizing how we will deal with truth and reconciliation. There is scope for acknowledgments and apologies for suffering inflicted on multiple sides, including by Palestinians.

This, in turn, leads us to a fourth facet of justice. Post-apartheid South Africa and post-Oslo Israel-Palestine are riven with problems of crime and deep social and economic inequalities. Many critics of the transition from apartheid in South Africa trace these problems to the failure to consider questions of socio-economic justice in that transition. ${ }^{11}$ Furthermore, there is a profound dignity gap as a result of incomplete efforts to achieve and fulfil some of the basic freedoms such as freedom from want, from fear, and freedom to live in dignity. Israel suffers from acute income inequality, as became vividly apparent in the protest movement in Tel Aviv in 2011. According to the OECD's report of March 2018, 'average disposable income of the $10 \%$ richest households was 13.3 times that of the poorest', a figure substantially higher than the median among other OECD countries of 9.4. ${ }^{12}$ By the same token, neoliberal policies of the Palestinian Authority have exacerbated deep class divisions in the West Bank. Poverty rates in the Gaza Strip are terrible, largely due to a ruinous siege of more than a decade, three major Israeli attacks and nearly daily violence by the Israeli military, on land and at sea. In such awful circumstances, how can one not just imagine how to end the Nakba, but also to build a humane society in which any of us would be proud to live?

This context is an important backdrop to Blake Alcott's contribution to this Special Issue, where he argues for centralizing the notion of legitimate citizenry in Palestine/Israel. His contribution explores the relative legitimacy of two opposing citizenries, one encompassing an ethno-religiously defined group whose vast majority is from outside Palestine, the other made up of indigenous people of whatever race or religion. Alcott shows that despite territorial absences, all Palestinians are significantly affected enough by whatever state rules historic Palestine to deserve citizenship. He concludes that no citizenry without them is legitimate, and a necessary condition of a state's legitimacy is that it has its legitimate citizenry. 
Gender and sexual preference justice is a fifth facet; both Israeli and Palestinian societies manifest patriarchy and sexual preference oppression in their specific ways. This is not just us importing our Western-derived values to Israel/Palestine. Rather, we take our cue from local feminists and queers. On the Palestinian side, women have long been expected to subordinate gender rights to national struggle - for no good reason. We must stand for gender and sexual preference justice everywhere, and now.

We must also account at some level for a sixth facet, namely environmental justice. In a place where injustices against humans abound, it is easy to neglect damages to the natural environment. Gaza may well be unlivable from an environmental perspective, as soon as 2020, according to some experts and the UN. Apart from the devastation of Gaza' s land and aquatic environments, Israel has plundered the occupied Territories of water and stone, used the territory as a dumping ground for sewage, garbage and industrial pollutants. The Palestinian Authority too has failed to be a responsible steward of the environment. Yet, protecting the environment is a matter of urgent concern, to all life in the region.

This brings us to the last, cross-cutting facet of justice we wish to address, namely regional justice. Israel has inflicted great harm on all of its neighbours at one time or another. To begin with, Israel cast hundreds of thousands of destitute refugees onto neighbours that were ill-equipped to absorb them. In addition, Arab societies were disfigured, robbed of vitality and diversity, by the loss of their Jewish communities due to large-scale emigration following Israel's establishment. While the circumstances of the departures of Mizrahi Jews from Arab countries has varied widely, there is no doubt that some suffered grave injustices that should be acknowledged and rectified. As discussed earlier, these injustices also include the treatment of Mizrahi Jewish citizens within Israel itself. ${ }^{13}$ The broader consequences of what Yiftachel has referred to as 'the Israeli ethnocracy', has resulted in widespread discrimination and abuse against Mizrahi as well as Haredi Jewish Israeli citizens, a situation that has further harmed the prospects for reconciliation between Israel and the Palestinians, though authors are quick to point out the lack of symmetry between those on the periphery of Israel' s regime, and that 'Palestinians have been far more affected' by the marginalizing consequences of Israel's policies. ${ }^{14}$

This last facet of regional justice also calls for a fundamental questioning of the concept of 'Jewishness', which Israel claims is fundamental to its legitimacy claim as a Jewish democratic state, and yet hardly has a homogenous character in Israel, let alone the rest of the world. It is in fact a highly contested and divisive concept, as Yakov Rabkin in his contribution to this Special Issue has argued. What Rabkin refers to as 'Judaic contestations' extend in the first instance to challenging the very ideology of Zionism, and in the second instance to how Israel eventually came into existence as a state. Accordingly, Rabkin has taken note of the views of a large and growing number of anti-Zionist Jews, who argue in favour of new reconciliation strategies, including a recognition of and reparation for the many injustices committed against Palestinians.

Is consideration of these multiple facets of justice premature? Possibly. Are we able to adequately capture the extent of Palestinian suffering and representation by addressing these facets? Probably not. The 2017 conference in Cork went a long way to rectifying this and included numerous voices from Palestine, who also had a leading role in its organization. While only a limited number of these voices made their way into written articles, the majority of Guest Editors and reviewers for this Special Issue were Palestinians. It is also important to note that all contributions reflect and reference Palestinian arguments and thoughts. We further understand that the Palestine Yearbook of International Law will also be publishing a special issue of papers emanating from the Cork Conference. There is certainly much more that has and will continue to be written on this topic, including by Palestinians scholars in this field. ${ }^{15}$

The more we flesh out the meaning of justice the more we hope to ignite support and enthusiasm, and, in light of the political difficulties surrounding the organization of the Cork conference, we also expect that this Special Issue will of course also ignite controversy. We can offer the world the model of another Arab police state or alternatively a model and vision of an enlightened and just society, that fosters diversity and sustainability in its relationship to the natural environment. Which model of statehood and justice is more likely to inspire support, and to mobilize people to action? And what role does international law have to play here?

\section{International law as a medium for justice}

This brings us to the role of international law as a medium for accomplishing justice and the implications of this for the principle of state illegitimacy. As the contributions to this Special Issue of the Global Jurist reveal, both statehood and justice are much more multi-faceted concepts than have been fielded in the past. For example, Ugo Mattei argues that, with regard to the use of international law to try and resolve the ongoing impasse between Israel and the Palestinians: 
Failing to be part of the solution, the law became part of the problem because it introduced into the already complicated puzzle all the issues of Orientalism, racism, identity, and self-indulging narrative that are part of the Western rhetoric on democracy and the rule of law.

For this reason, and others addressed at the 2017 conference in Cork and contained in this Special Issue, we acknowledge the widely-held scepticism about the role of international law in resolving the impasse between Israel and the Palestinians, though we are also of two minds. On the one hand, we recognise the value of international law in enshrining Palestinians demands for self-determination, dignity, justice and equality as well as statehood. ${ }^{16}$ Accordingly, we recognise the role international law serves to underpin the legitimacy of the Palestinian call for Boycott, Divestment and Sanctions. ${ }^{17}$ On the other hand, we have grave doubts that the systems administering international law currently have the tools to ensure justice in Israel/Palestine, especially in the absence of effective accountability mechanisms and the presence of dysfunctional global governance institutions. ${ }^{18}$ Many liberation struggles, including the struggle against apartheid, have succeeded without underscoring a principle of state illegitimacy.

Here we have to be careful not to be bewitched by law's promise, not to expect law to outrun politics, and deliver victories that have not been earned on the field of political struggle. We say this because some of us may have high expectations, for example, of the International Criminal Court and the promise of securing justice for the many Palestinian victims of individual perpetrators of international crimes.

Bayard Rustin, a prominent strategist of the civil rights movement in the United States publicly observed in 1961: "Unjust social laws and patterns do not change because supreme courts deliver just decisions ... Social progress comes from struggle: all freedom demands a price."

Rustin reminds us that courts make socially and politically progressive decisions only when forced to by a mobilized citizenry. This, we argue, is just as true of international courts as it is of domestic courts. Hence, we must be guarded in our expectations of what to expect from law.

This is not to say that international law is inconsequential. No South African official was ever tried under the International Convention on the Suppression and Punishment of the Crime of Apartheid, but its adoption by the General Assembly of the United Nations in 1973 was surely not an idle act. Highlighting South Africa's policies of apartheid dramatically expressed the moral outrage of a segment of the international community that helped to transform public discourse about South African apartheid. The same is true of Richard Falk and Virginia Tilley's report on Israel's treatment of the Palestinian people as constituting the crime of apartheid, which no doubt forms a substantial reason why the report has been officially suppressed. ${ }^{19}$

Ugo Mattei, in his contribution to this Special Issue, urges us to reconsider our state-centred preoccupation with international law. Instead, to regard the Nakba that has affected the Palestinians 'be seen as part of a general consequence of legal modernization, that we can call the 'catastrophe of the commons'. Thinking 'outside the box of modernity', Mattei suggests, will allow us to think of more creative solutions, such as a 'No-State solution'. However, whatever just 'solution' is found, we would argue that a pre-requisite of any requires redressing the power imbalance between Israel and the Palestinians and ending Israel's decades-long occupation. ${ }^{20}$

Whether or not one might support a more radical solution such as Mattei's, the papers in this Special Issue all confirm that the legitimacy of the Israeli state, framed as a Jewish state, profoundly lacks legitimacy. Undoubtedly, there is a need for more robust institutional arrangements to ensure a just future for all in the embattled region known as Israel-Palestine.

Law itself may not deliver us all the answers we seek. But if we who work in the field of law put our shoulders to the wheel along with others pushing in their own domains; in other words, if we effectively integrate the legal with other forms of struggle, justice will at least come a little closer.

\section{Notes}

1 R. Khalidi (2017) 'Historical Landmarks in the Hundred Years' War on Palestine' Journal of Palestine Studies, 47(1): 6-17.

2 N. Hijab and D. Buttu (2014) 'PLO/Palestine: time to stop buying time' Al Shabaka, November 13, last checked on 16 July 2018 at: https://al-shabaka.org/commentaries/plopalestine-time-to-stop-buying-time/

3 N. Hijab (2015) 'The Palestine state project in question' Al Shabaka, October 26, last checked on 16 July 2018 at: https://alshabaka.org/commentaries/the-palestine-state-project-in-question/; K. van der Borght (ed.) (2011) Imagining a shared future: perspectives on law, conflict and economic development in the middle east London: Cameron May.

4 However, see Mazen Masri (2017) The dynamics of exclusionary constitutionalism: Israel as a Jewish and democratic state London: Bloomsbury and A. Abunimah (2006) One country: a bold proposal to end the Israeli Palestinian impasse New York: Metropolitan Books and J. Schehla (2001) 'The Invisible People Come to Light: Israel' s "Internally Displaced" and the "Unrecognized Villages"' Journal of Palestine Studies, 31(1): 20-31.

5 W. Khalidi (1992) All that remains: the Palestinian villages occupied and depopulated by Israel in 1948 Washington D.C.: Institute for Palestine Studies; N. Masalha (1992) Expulsion of the Palestinians: The Concept of Transfer in Zionist Political Thought: 1882-1948 Washington D.C.: Institute for Palestine Studies; N. Masalha, A land without a people (London: Faber and Faber, 1997; I. Pappe (2006) The ethnic cleansing of Palestine London: One World; A. Shlaim (2001) The war for Palestine: rewriting the history of 1948 Cambridge: Cambridge University Press. 
6 N. Hijab and M. Rabbani (2017) ‘Tracking the trends of the Palestinian cause since 1967`Al Shabaka, June 5, last checked on 16 July 2018 at: https:/ /al-shabaka.org/commentaries/tracking-trends-palestinian-cause-since-1967/

7 G. Robinson (1997) Building a Palestinian state: the incomplete revolution Bloomington, IN: Indiana University Press at pp. 94-131

8 J. Handmaker (2011) 'Beyond Exclusion: Assessing Palestinian refugees' struggle for protection and recognition and their potential contribution to a peace settlement' in K. van der Borght (ed) Op Cit (pp. 197-222).

9 G. Bisharat (2008) 'Maximizing Rights: The One State Solution to the Palestinian-Israeli Conflict' Global Jurist 8(2): 1-36; G. Karmi (2011)

'The One-State Solution: An Alternative Vision for Israeli-Palestinian Peace' Journal of Palestine Studies 40(2): 62-76.

10 See also M. Kagan (2005) ‘Do Israeli Rights Conflict With the Palestinian Right of Return?' BADIL Working Paper No. 10 Bethlehem: BADIL Resource Centre on Palestinian Residency and Refugee Rights.

11 A. Clarno (2017) Neoliberal apartheid: Palestine/Israel and South Africa after 1994 Chicago: University of Chicago Press.

12 OECD (2018) OECD Economic Surveys: Israel Paris: Organization for Economic Co-operation and Development, at p. 40, last last checked on 16 July 2018 at: https:/ /www.oecd.org/eco/surveys/Israel-2018-OECD-economic-survey-overview.pdf

13 S. Lavie (2014) Wrapped in the flag of Israel: Mizrahi single mothers and bureaucratic torture Lincoln: University of Nebraska Press.

14 O. Yiftachel (1997) 'Israeli society and Jewish-Palestinian reconciliation: "ethnocracy" and its territorial contradictions' Middle East Journal 51(4): 505-519 at 506.

15 See: Abunimah, Hijab, Khalidi, Masri and others, Op cit.

16 J. Quigley (2010) The statehood of Palestine: international law in the middle east conflict Cambridge: Cambridge University Press.

17 O. Barghouti (2011) Boycott divestment sanctions: the global struggle for Palestinian rights Chicago: Haymarket.

18 S. Akram, M. Dumper, M. Lynk and I. Scobbie (Eds.) (2011) International law and the Israeli-Palestinian conflict London: Routledge.

19 United Nations (2017) Israeli practices towards the Palestinian people and the question of apartheid Beirut: Economic and Social Commission for Western Asia. Also available, last last checked on 16 July 2018 at: https://electronicintifada.net/sites/default/files/201703/un_apartheid_report_15_march_english_final_.pdf

20 A. Tartir (2016) ‘Palestine-Israel: Decolonization Now, Peace Later' Mediterranean Politics 21(3): 457-460. 